\section{Using NICTs for Media Interpreting Training: Bringing Interpreter-Mediated TV News and Radio Interviews to the Classroom}

\author{
Pedro Castillo
}

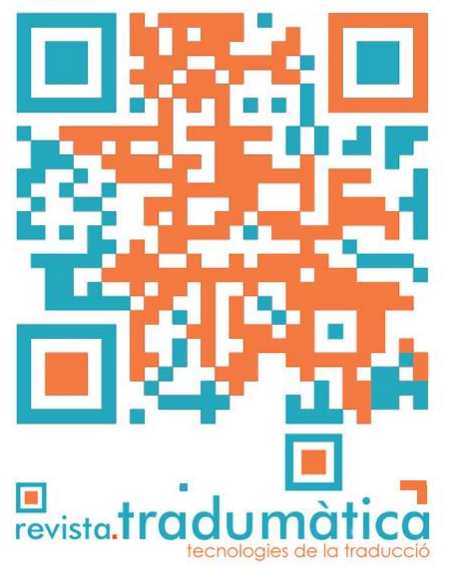

Abstract

This paper discusses how the impact of the revolution of NICTs on interpreters' work in the media can be transposed to the interpreting classroom. This article focuses on the use of sound and video editing software by interpreters for producing prerecorded interpreter-mediated news features for TV and live dialogue radio interpreting. The main purpose is two-fold: 1 ) to acknowledge the potential of NICTs for interpreter training in a practical context; and 2) to build a pedagogical model based on the pioneering practice of media outlets such as ARTE, the French-German broadcasting company, and RTVE, the Spanish public broadcaster.

Keywords: Interpreter training, Media Interpreting, Dialogue Interpreting, NICTs

Resum

L'objectiu general d'aquest article consisteix a argumentar la manera de traslladar l'impacte de la revolució de les noves tecnologies de la informació i la comunicació (New Information and Communication Technologies, NICTs) sobre el treball dels intèrprets als mitjans de comunicació a les aules d'interpretació. Ens hem centrat en l'ús de programes d'edició de so i de vídeo per part dels intèrprets per produir fragments de notícies pregravades per a la interpretació de diàlegs en directe a la televisió i a la ràdio. El propòsit principal és doble: (1) reconèixer el potencial de les NICTs per a la formació d'intèrprets en un context pràctic $i$ (2) construir un model pedagògic basat la pràctica pionera d'alguns mitjans de comunicació com ara ARTE, l'empresa de difusió francoalemanya, i RTVE, la televisió pública espanyola.

Paraules clau: Formació d'intèrprets, interpretació als mitjans de comunicació, interpretació de diàlegs, NICTs

\section{Resumen}

El objetivo general de este artículo consiste en argumentar el modo de trasladar el impacto de la revolución de las nuevas tecnologías de la información y la comunicación (New Information and Communication Technologies, NICTs) sobre el 
trabajo de los intérpretes en los medios de comunicación a las aulas de interpretación. Nos hemos centrado en el uso de programas de edición de sonido y de vídeo por parte de los intérpretes para producir fragmentos de noticias pregrabadas para la interpretación de diálogos en directo en la televisión y en la radio. El propósito principal es doble: (1) reconocer el potencial de las NICTs para la formación de intérpretes en un contexto práctico y (2) construir un modelo pedagógico basado en la práctica pionera de algunos medios de comunicación como ARTE, la empresa de difusión franco-alemana, y RTVE, la televisión pública española.

Palabras clave: Formación de intérpretes, interpretación en los medios de comunicación, interpretación de diálogos, NICTs

\section{Introduction}

Media interpreting (MI), especially on TV, has been the focus of an increasing body of research over the last 20 years, with an exponential increase in research literature in the last decade. This is most likely due to the fact that scholars have gained easier access to interpreter-mediated data, as well as to the high degree of exposure that Ml has provided to practicing interpreters (cf. Castillo 2015b, Jiménez Serrano 2011, Pöchhacker 2007). However, it can be argued that the growing body of scholarly work on Ml has not, as yet, had a significant impact on the training of future interpreters, based on the scant literature on the use of interpreter-mediated broadcasts for training purposes. Although there have been attempts to create media-based corpora to take advantage of interpreter-mediated broadcasts for training purposes (Castillo 2015a, Jiménez Serrano 2011, Straniero Sergio 2011, Sandrelli 2012), no project has yet come to light that has systematised such data and produced a pedagogical model to make the most of this type of interpreting for training purposes, along the lines of the model developed by de Manuel Jerez (2003, 2006). Neither has Ml been included in interpreter training curricula at undergraduate or postgraduate levels, as suggested by Castillo (2015a).

The purpose of this paper is to discuss the impact of the revolution of NICTs (New Information and Communication Technologies) on interpreters' work in the media, most notably on TV and radio. Furthermore, to show how interpreter-mediated TV and radio broadcasts can be used for interpreting training purposes with the enhancement of new technologies, i.e., audio editing tools, within a pedagogical framework which takes into account the organisational, interactional and discursive aspects of dialogue interpreting in radio settings $(2015 \mathrm{a})$.

Media interpreting (MI) is a growing field within interpreting research (e.g. Castillo 2015b, Falbo 2011) and the profession (e.g. AllC 2012). Yet, in spite of the growing number of interpreter-mediated broadcasts available on TV, radio and online, their potential for training purposes is still underdeveloped, or at least not documented in the literature. This article specifically explores TV news reports including short interviews, and interpreter-mediated live radio interviews in which dialogue interpreting is provided. In my previous research (Castillo 2015a), I concluded that radio interviews can bridge a common gap in training dialogue interpreting: the challenge of providing interpreting students with original dialogues, as well as creating authentic settings for this modality in which to 
practice their interpreting skills. This claim can also be applied to TV interpreting; TV and radio still constitute the main core of the so-called mass media.

Building on previous work in interpreter training action research (de Manuel Jerez 2003, Sandrelli and de Manuel Jerez 2007), the project presented here offers a practical application in consecutive, simultaneous and dialogue interpreting classes using edited interpreter-mediated broadcasts from the French-German broadcasting company ARTE and RNE, the Spanish public radio service. Editing for training purposes consists of the following: in the case of TV news, video/audio software (Pro Tools or similar free software) is used to produce voiceovers of news pieces which include interviews or statements in a foreign language, following ARTE's now customary practice (Krone 2010) and technical specifications (ARTE G.E.I.E. 2012). In the case of radio interviews, audio software (Audacity) is used to remove interpreters' utterances from the broadcast piece and leaving those spaces blank for students to interpret as if it were live interpreting, following RNE's Radio 3 practice. Based on observational ethnographic research and the broadcast information provided by the media institution, the interpreting conditions are replicated in the classroom by showing images of the setting where the interviews take place, re-enacting the situational arrangements and the on/off-air levels of interaction. Special emphasis is put on class exercises which tackle key organisational aspects of different live radio interview settings, e.g., studio interaction, studio-to-studio interaction and studio-to-remote location interaction.

Examples of actual exercises at different stages of interpreter training (undergraduate, MSc, Ml workshops for practitioners) which I have conducted in the last 10 years are provided, paving the way for a project to systematise such data and produce a pedagogical model to make the most of Ml for training purposes. Technologies as diverse as traditional media (radio), web-based media platforms (podcasting) and audio software interact to enhance the students' learning experience.

\section{NICTs and interpreter training}

Braun (2006:1) argues that:

the ongoing spread of information and communication technologies along with growing multilingualism and efforts of social inclusion (access to the media for all) has led to changes in communication practices, which have also had repercussions on the practice of interpreting at the beginning of the 21st century.

Technological developments such as teleconferencing technologies, webcasting and podcasting have resulted in "some relatively new forms of interpreting and have created additional and/or novel tasks for interpreters" (Braun, 2006:2). There is no doubt that NICTs have revolutionised the ways interpreting is taught. As de Manuel Jerez argues (2003), the amount of material that can be used for both class and self-study interpreting practice has grown exponentially since we entered the era of the internet and digital media. Amongst the main advantages and potential of new technologies for interpreter training, he mentions the following: 
[...] have access to material extracted from real situations that incorporate the oral dimension [into training] together with features of non-verbal language, images of the physical space where the communicative event takes place in the case of video recordings [...] and, above all, broadening the range of real speeches to [include] those delivered spontaneously (in traditional forms of training, spontaneous speeches are not real and real speeches are not spontaneous). (de Manuel Jerez, 2003:23, my translation) ${ }^{1}$

This access to real interpreter-mediated material has been made even easier since the so-called YouTube (and similar platforms) revolution as well as TV and radio on demand, which offers the possibility to access vast amounts of data that was otherwise inaccessible just 15 years ago. In spite of these enormous advantages, the introduction of more authentic and easily accessible data in interpreter training programmes is not without its challenges. As Bao (2015) argues:

As it is often assumed that students themselves are responsible for their own practice, especially graduate students who are supposed to know how to study, practice is very often left in the hands of the students. But the truth is that it may take a while for students, especially in their first semester, to find the right approach to practice. Without specific assignments given by the instructor, students often do not know what to practice with and how. For the training to produce the desired results, it is useful to integrate student self-study and practice into the curriculum and provide guidance accordingly. In some programs, students are given credit for self-study, and well-structured practice materials are provided. (Bao, 2015:413-414)

This warning call is shared by Braun et al. (2013), who substantiate their argument with education theories and subsequently suggest a greater implication of trainers in integrating NICT-based interpreter training platforms which have been developed in the last 20 years and are being used with some degree of success in interpreting training programmes, mostly for conference interpreting (Berber 2008). These platforms basically consist of audio/video repositories and spoken language corpora for interpreter training purposes. Examples include the Speech Repository by the DG Interpretation (SCIC), the ORCIT website (Online Resources for Conference Interpreter Training) and the European Parliament Interpreting Corpus (EPIC), all of which principally address the needs of conference interpreter training (Braun et al., 2013:95) and focus "rather exclusively on self-study and individual practice" (2013:97). Nevertheless, these platforms tend to be limited in terms of the number of languages and language combinations, although with successful examples of progress being made in recent years, such as the Speech Repository. They also lack an integration of computer-assisted interpreter training (CAIT) packages "which offer digital content along with bespoke learner and authoring functions for an interpreting context" (Braun et al., 2013:97). Although this represents significant progress in interpreter training and these packages are increasingly being used in the classroom (Berber 2008), the pedagogical model behind them has fostered self-guided and autonomous learning. This only satisfies cognitive constructivist principles of learning and omits "principles of a social constructivist approach to learning (Vygotsky 1978)"

\footnotetext{
${ }^{1}$ Original citation: "[...] acceder a material tomado de situaciones reales incorporando la dimensión oral, así como, en el caso de las grabaciones en vídeo, elementos del lenguaje no verbal de los oradores, imágenes del espacio físico en que se desarrolla la comunicación [...] y, sobre todo, abrir el abanico de los discursos reales a los pronunciados de forma espontánea (en la formación tradicional los discursos espontáneos no son reales y los reales no son espontáneos."
} 
which highlight "the importance of the social embedding of learning for the process of knowledge construction" (Braun et al., 2013:97). Following this approach would involve, according to Kiraly, a combination of "authentic situated action, the collaborative construction of knowledge, and personal experience" (2000:3). Projects such as ORCIT and InterpretimeBank are illustrative examples of approaches that encourage collaboration in content creation based on personal and professional experience.

These shortcomings were addressed, and to some extent remediated, by arguably more advanced projects such as the Marius database (de Manuel Jerez 2006) and CAIT authoring programmes such as Interpr-IT and Black Box 3.0 with which "trainers are able to create exercises to train students in all interpreting modes, i.e. simultaneous, consecutive and liaison interpreting, as well as sight translation" (Sandrelli and de Manuel Jerez, 2007:289). De Manuel Jerez $(2003,2006)$ specifically aligns with Kiraly's approach in terms of how interpreting trainers make use of online materials for interpreting. In this sense, he (de Manuel Jerez 2003: 23) anticipates Bao's concerns (2015; see above) regarding platforms/projects such as the Speech Repository and ORCIT by acknowledging that the selection of AV material for interpreting training purposes entails certain risks and recommending that the following three aspects be taken into consideration when selecting AV material for interpreting training purposes, to ensure coherence:

- Professional reality.

- How technological advances can help us bring this reality into interpreting laboratories.

- How and when to introduce material thus obtained into interpreter training.

Some innovative projects using NICTs have also been carried out in other fields of interpreting practice, although few results have been reported in research as to how effective these projects are. However, it is worth noting that they do exist: in business interpreting Hansen and Shlisinger (2007) (referenced in Braun et al. 2013:96) outlined an initiative to develop video-based interpreter training at the Copenhagen Business School, based on bilingual role-play dialogues for self-study purposes. The video clips were accompanied by additional materials including "background documents, written texts for sight translation, Power Point presentations and glossaries, as well as tasks and exercises (Hansen and Shlisinger, 2007:105-106).

In the field of public service - or community - interpreting, Tymczyńska (2009) follows the principles of social constructivism and student-centred collaborative instruction. She combines the provision of training materials (with in-class role plays as core practice training) and Course Management Systems (CMS) like Moodle, which are now widely used in academic institutions around the world. Tymczyńska (2009) follows Gómez and Weinreb ' s (2002) principle when designing a course combining online and in-class activities at Adam Mickiewicz University (AMU), Poznań, that is: "pedagogy must drive the technology and not vice versa. Technology is an important tool, but as with any tool, it is useful only if one knows how to use it advantageously" (Gómez \& Weinreb 2002: 643). One of the main advantages of CMS, according to Tymczyńska, is that: 
Instructors may upload a varied didactic content to enable students to integrate the information more effectively while catering to a variety of learning styles (cf. Leaver et al. 2005: 65-81), namely:

- Visual Learners who benefit most from visual displays including: pictures, diagrams, illustrations, videos;

- Auditory Learners who learn through listening to audio and video materials;

- Tactile/Kinaesthetic Learners who profit from doing interactive online exercises and self-assessment tests. (Tymczyńska, 2009:156)

Although most of these projects are ongoing, ${ }^{2}$ what seems clear is that the turn of the 21 st century has seen a move towards a social constructivist and communicative approach (cf. Sandrelli 2015), as evidenced by Kiraly (2000), de Manuel Jerez (2003, 2006), Sandrelli and de Manuel Jerez (2007), (Hansen and Shlisinger 2007) and Tymczyńska (2009).

NICTs give interpreter trainers an unprecedented opportunity, moving beyond traditional teaching strategies such as staging dialogues in class or playing pre-recorded speeches to be interpreted simultaneously or consecutively by students. Using NICTs, trainers can gather examples of interpretations that have been broadcast on TV, radio or online and edit them in a way that allows students to step into the shoes of the original interpreter and create their own interpretation, under the same or similar conditions. This does not only mean that students can compare their own work with that of professional media interpreters, but also increases their motivation by bringing authentic examples of interpreting into the classroom.

\section{NICTs and Ml training}

When it comes to $\mathrm{Ml}$, however, research and literature on the pedagogy of $\mathrm{Ml}$ is even scarcer and there have been few attempts to bring increasing knowledge on $\mathrm{Ml}$ into the classroom in a systematised way (cf. Castillo 2015b). Yet, Berber's (2008) hypothesis that more and more interpreter trainers use interpreter-mediated broadcast material in their classes (most often in conference interpreting classes), as colleagues from the UK and Spain have confirmed to me informally, seems to be not far from reality. The success rate of these practices, however, has not been studied empirically. The use of interpretermediated broadcasts as class material has probably been going on for some time, but judging by the different under/postgraduate course programmes and syllabuses under scrutiny here (e.g. EMCI 2014), no systematic, comprehensive, corpus-based pedagogical proposal that includes $\mathrm{Ml}$ as part of this syllabus has yet been put forward. Pedagogical models conceived mainly for conference interpreting seem to have prevailed as the norm to be followed in different interpreting contexts (cf. Seleskovitch 1978, Gentile 1997), even though in recent years the specific demands and features of different fields of interpreting practice have increasingly been acknowledged (cf. Mikkelson 2010, Mikkelson and Jourdenais 2015, Martin 2015, Colina and Angelelli 2017). It is worth noting that

2 It is worth taking note of the potential of 3D learning environments (e.g. Braun and Slater 2013). As Sandrelli (2015:119) puts it, with 3D learning environments "the idea is to create 'immersive' simulations of environments in which students can 'meet' to practise interpreting in a conference centre or court or other venue." 
key works on interpreting research and training have not yet capitalised on the potential of interpreter-mediated broadcasts as a useful training tool. Perhaps more surprisingly, they continue to leave Ml out of the Interpreting training equation (cf. Napier 2013, Gile 2009, Zhong 2010, Gonzalez-Davies and Enríquez Raído 2016, ${ }^{3}$ Fantinuoli 2018) or just refer to it en passant without researching it in more depth (e.g. Braun 2006, ISIT 2015, Gillies 2019).

On the other hand, some skills and challenges can be common to interpreting across modalities and fields of practice (Gile 2009), and although their weight may vary from one modality/field of practice to the next, training exercises can be adapted to the specificity of these fields of practice on the basis of thorough institutional, discursive and communication research. In this sense, role plays and interpreting drills have been - and still are - common practice in interpreter training (particularly in dialogue interpreting in the field of public service interpreting, and conference interpreting) and they are being used systematically with a certain degree of success (e.g. Wadensjö 2014, Zhong 2010). Yet they still run the risk of not being perceived by trainees as sufficiently authentic, ${ }^{4}$ which, in turn may diminish both trainee motivation to carry out the exercises and trainers' credibility when it comes to using these types of exercises adapted to Ml. This is not to say that Ml can only be taught through exercises that use actual broadcast material, but it is a warning that any replication of real-life situations should be backed by a thorough knowledge of the media, including production practices and what happens on and off the broadcast. Furthermore, replicating broadcasting studio conditions in the interpreting lab is subject to potential technical limitations in the latter. However, with field and ethnographic research, it is possible to get to know Ml production conditions, as well as how $\mathrm{Ml}$ is used to serve language transfer purposes in media broadcasts. Thanks to research of this kind (cf. Castillo 2015b, Gieve and Norton 2007, Krone 2012, see below), plus technical details on language transfer (including translation, interpreting and accessibility services) that public broadcasters make public as part of their public service remit, today we know that $\mathrm{Ml}$ is highly diverse. Combining the results of these branches of research will enable us to replicate these diverse conditions both inside and outside university classrooms.

When it comes to the use of NICTs, there are empirical grounds to argue that $\mathrm{Ml}$ is intrinsically tied to the advances in technologies in media broadcasting (e.g. ARTE G.E.I.E. 2012, Krone 2010), thus making it a field of research that cannot ignore either the potential or the challenges that NICTs pose for the practice and training of media interpreters. Thanks to technology, the spectrum of ways in which interlingual communication needs are dealt with in the media is arguably wider than in any other field of interpreting practice (cf. models by Gieve and Norton 2007, and Castillo 2015b, see tables below).

\footnotetext{
${ }^{3}$ The Interpreter and Translator Trainer devoted a monographic edition (Volume 10, Issue 1, 2016) to situated learning, called Situated Learning in Translator and Interpreter Training: Bridging research and good practice. Even though the diversity of situated learning context in the issue is wide, no study on $\mathrm{Ml}$ is presented, providing a further example of the fact that it has not yet been included in mainstream areas of research.

${ }^{4}$ Understood here in terms of Pacheco Aguilar (2015:13-32).
} 
In their study of how British television deals with linguistic difference in encounters with the other, Gieve and Norton (2007) offer one of the first attempts to classify the strategies for dealing with linguistic difference on broadcast television systematically (including interpreter-mediated and non-interpreter-mediated encounters). For the purposes of this article, a key contribution of Gieve and Norton's study is a model which critically describes "how the production as a whole articulates and mediates the relationship between the protagonist, audience and the FL speaker as broadcast, through pre-, during- and post-filming strategies." In the second stage of their descriptive analysis, Gieve and Norton (2007:194-206) identify strategies for the representation of linguistic difference that they summarise in the following table: ${ }^{5}$

\begin{tabular}{|c|c|c|}
\hline Pre-filming strategies & During-filming strategies & Post-filming strategies \\
\hline $\begin{array}{c}\text { Selecting English speakers } \\
\text { as informants }\end{array}$ & $\begin{array}{c}\text { Intermittent report / } \\
\text { narration / explanation by } \\
\text { protagonist }\end{array}$ & $\begin{array}{l}\text { Voice-over interpretation } \\
\text { and dubbing }\end{array}$ \\
\hline $\begin{array}{l}\text { Avoiding interaction with } \\
\text { non-English speakers }\end{array}$ & Non-verbal communication & Subtitling \\
\hline Providing interpreters & Pseudo-interaction & Narration \\
\hline \multirow[t]{4}{*}{$\begin{array}{l}\text { Selecting a presenter } \\
\text { competent in the FL }\end{array}$} & $\begin{array}{l}\text { Use of an Interpreter, } \\
\text { on/off-screen }\end{array}$ & $\begin{array}{l}\text { Editing out real-time } \\
\text { interpreter participation }\end{array}$ \\
\hline & $\begin{array}{c}\text { Consecutive translation by } \\
\text { protagonist }\end{array}$ & \\
\hline & Foreigner talk & \\
\hline & Lingua franca talk & \\
\hline
\end{tabular}

Table 1: Summary of strategies used in dealing with encounters across linguistic difference in British television (Gieve and Norton, 2007:207).

Beyond the political and ideological implications of these strategies (Gieve and Norton, 2007:208), a key contribution of this study for interpreter training is that it breaks away from a monolithic view of TV interpreting as a practice that typically takes place live, in either consecutive or simultaneous mode, therefore opening up opportunities for a wider range of practices that through research, could be turned into training exercises and skills.

Castillo and Comte (2010 and 2011) take a step further in the exploration of interpreting practices in TV and radio production with the research-based documentaries

${ }^{5}$ The table excludes news reports and political interviews (Gieve and Norton, 2007:206). Although the categorization does not draw on exhaustive quantitative analysis, the authors mark the most commonly found strategies in bold. 
The Behind the Scenes Journey of TV Interpreting (2011) and The Role of the Broadcaster in an Interpreter-Mediated Radio Interview (2010), which offer audio-visual evidence of the creation and production mechanisms in a multilingual television programme requiring interpreters and in live radio interviews, respectively. Castillo and Comte (2010 and 2011) show the collaborative nature of media production, which must be taken into consideration when it comes to interpreter-mediated events. Moreover, as Castillo (2012:85) argues following his data analysis:

Media stakeholders' views and approaches to interpreting sometimes collide or need to be negotiated, and it is the level of language and interpreting awareness, experience and collaborativeness of the production team that ultimately shape the way interpreting is performed and broadcast.

As opposed to Gieve and Norton (2007:208), who suggest an 'ideal approach' which recognises that linguistic differences do exist, in predictable as well as unpredictable contexts, Castillo and Comte (2011) and Castillo (2012) argue that the 'ideal approach' does not a priori guarantee a successful interpreter-mediated exchange. Nonetheless, both studies provide evidence leading to a common premise: when the organising institutions are aware of language issues and are happy not to try to conceal linguistic differences, they employ comprehensive, integrating production mechanisms - including the provision of interpreters from the beginning of the production - to satisfy the interlingual and intercultural needs of the broadcast. Furthermore, one should not overlook the pedagogical value of gathering data and presenting it in the form of a film documentary that can be used to contextualise an authentic immersion into TV interpreting prior to working with exercises of the type suggested in this article.

Along the lines of Gieve and Norton's summary table (see above), Castillo (2015a:301/2015b:281) researched media interpreting practices in interpreter-mediated interviews. Castillo's descriptive framework of practice, as summarised in the table below (Castillo 2015a:301/2015b:281), broadened the previously documented spectrum of situational arrangements and broad patterns of interaction in MI. Attempts to describe the "backstage conditions" of TV interpreting (Jiménez Serrano 2011) and to categorise interpreter-mediated TV events and interviews (Alexieva 1999 and 2001, respectively) did not look into these aspects systematically and it could be argued that the map of Ml practices was incomplete, with radio interpreting not featuring at all.

Location $\bigcirc$ Studio




\begin{tabular}{|c|c|}
\hline & $\begin{array}{l}\text { Outdoors/ On Location Studio } \\
\text { Remote: Studio-to-studio } \\
\text { Remote: Studio to private home }\end{array}$ \\
\hline Broad pattern of interaction & $\begin{array}{l}\text { Face-to-face } \\
\text { Face-to-face, multi-party interview } \\
\text { Studio-to-studio connection } \\
\text { Phone connection }\end{array}$ \\
\hline Mode of Interpreting & $\begin{array}{l}\text { Dialogue } \\
\text { - Mixed: Simultaneous/Dialogue }\end{array}$ \\
\hline
\end{tabular}

With such models to account for Ml practices, more realistic training exercises based on interpreter-mediated broadcasts are possible, particularly thanks to the use of NICTs that give way to innovative training methods and exercises, as argued in the previous section. The following sections focus on how this can be put into practice.

\subsection{Building on interpreter-mediated broadcasts: ARTE and RTVE}

As we have seen above, the body of research on $\mathrm{Ml}$ is growing, largely focusing on descriptive accounts of what Ml entails and how it works in different broadcasters and/or countries, using both spoken and sign languages (e.g. Mizuno 1997, Molina Vallecillo 2002, Darwish 2006, Shibahara 2009, Tsuruta 2011, Jiménez Serrano 2011, Castillo 2015b). Studies have investigated the challenges that interpreters face and specific skills that are required (e.g. Daly 1985, Kurz 1997, Kurz and Bros-Brann 1996, Straniero Sergio 2003, 2011), as well as looking into organisational aspects and interactional and discursive aspects (e.g. Wadensjö 2000, 2008, Straniero Sergio 1999, 2012, Katan and Straniero Sergio 2001, 2003, Gieve and Norton 2007, Castillo 2015a).

These studies have one methodological aspect in common: they all look at real interpreter-mediated practice, whether it is at the level of whole TV/radio stations, specific programmes, events or interactions in the media. There have also even been attempts to build corpora that can be used to find patterns, as a basis for potential training, or both (see specifically the volume edited by Falbo and Straniero Sergio 2011, but also Falbo 2012, Sandrelli 2012). As Falbo (2011: XVI) argues: "studying TI through corpora is a further step towards new interrogation paradigms, new methodological challenges and, hopefully, more ecologically comparable results." Therefore, corpus-based approaches to $\mathrm{Ml}$ are not only possible, but desirable if training in $\mathrm{Ml}$ aims to be representative of real practices.

For the purpose of this study, I draw on two main public broadcasters (ARTE and RTVE) with a long history of interpreting practice in their broadcasts and whose organisational and interactive aspects have been researched systematically in order to 
lend authenticity to the training exercises suggested below. The samples of interpreting available from these broadcasters are limited to four languages (English, French, German and Spanish), but it is hoped that they can be replicated and extended to other languages according to trainers' needs.

\section{Methodology}

Based on the social constructive approaches reviewed earlier, which advocate situated learning issuing from action-research methods, this paper offers a case study of a small sample of interpreted news and interviews on TV and radio, to be interpreted and recorded by students using free and accessible software, such as Audacity or Pro Tools. Following the model created by de Manuel Jerez (2006) for establishing parameters of difficulty that help systematise the use of interpreted events in class, the guidelines and practice of pre-recorded interpreting of news pieces on ARTE (ARTE G.E.I.E. 2012) and the study of organisational, interactional and discursive aspects of dialogue interpreting in radio settings by Castillo (2015a), the suggested activities can be part of both an authentic and productive situated learning process and of a larger framework of interpreter training which, as Kiraly argues, is "embedded in [its] larger, natural complex of human activity" (2000:43).

This model encourages students' in-class as well as guided independent practice, and it requires a prolonged interaction with NICTs. It also focuses on key Ml skills such as use of the voice and engaging with common news and interview discourses, which all form part of a set of training activities which motivate students to practice interpreting and improve their delivery skills from the early stages of their training.

This model also attempts to address the aims and programme guidelines established by the $\mathrm{EMCl}$ (European Masters in Conference Interpreting) agreement (2014), specifically when it comes to emphasizing the need for systematic training and guiding individual and group self-directed study (EMCI 2017)

\section{Suggested practices of TV and Radio interpreting using NICTs: stages and dynamics}

The exercises are grouped into two main blocks by interpreting modality. The following description highlights the key features that make each type of clips suitable for interpreting practice, thus permitting trainers to identify the relevant criteria when researching their own exercise material. As general preparation for both types of exercises, students are provided with background information on the broadcasting institutions, the TV channel and radio station, and the programmes where the interpretedmediated interviews take place, with special emphasis on analysing the respective communicative ethos (Scannell 1988), as a way of anticipating discursive and interactional aspects that may be relevant to the interpretation.

1. TV interpreting: Here, a set of unedited 1-2-minute clips from the Tour de France cycling race is used. They are monolingual interviews with cyclists which are typically interpreted consecutively for the live broadcast. The interviews are 
accompanied by basic background information about each Tour de France stage visible on the screen. These videos will allow students to practice both consecutive and simultaneous interpreting by voicing over the interviews and self-editing them with Pro Tools or similar software. The final news report to be broadcast will include a summary of the stage and the interpreter pre-recorded stage winner interview. ${ }^{6}$ The suggested duration of this exercise is 2 hours if practised as inclass exercise or 1-2 days to produce the edited piece if practised as homework or self-study exercise, in line with ARTE's practices, as described by Krone (2012:99). With regards to feedback and post-exercise discussion, a transcription of the interview following de Manuel Jerez's model (2006), inserted in a table laying out the stage winner's main discursive points, is handed out to students for class discussion and self or peer-to-peer assessment.

2. Radio interpreting: The clips in this category are excerpts from a film programme on the Spanish radio station Radio 3 called El Séptimo Vicio. They consist of bilingual interviews which are broadcast with live dialogue interpreting. For the exercise the interpretation is edited out of each clip, allowing students to record their own dialogue interpretation. The radio studio conditions, having been researched and documented beforehand, are replicated in the classroom by showing images of the original setting, as well as re-enacting the situational arrangements and the on-air off-air levels of interaction. The following example is put forward for illustrative purposes for a post-beginner-to-intermediate dialogue interpreting exercise:7

\begin{tabular}{|l|l|}
\hline & $\begin{array}{l}\text { Radio 3 (RTVE): El Séptimo Vicio. Interview with Viktor } \\
\text { Kossakovsky (Russian documentary filmmaker). } \\
\text { Date: 13/03/2013. } \\
\text { Duration of the whole episode: 1 hour. } \\
\text { Duration of the interpreter-mediated interview: 15:35-57:45 } \\
\text { (40min 10sec). } \\
\text { Languages: Spanish and English. }\end{array}$ \\
\hline \multirow{3}{*}{ Programme details: } & $\begin{array}{l}\text { Title on El Séptimo Vicio’s podcast website: Kossakovsky } \\
\text { quiere a Tolentino en su próxima película. [Kossakovsky }\end{array}$ \\
& $\begin{array}{l}\text { Additional Episode Metadata (see Episode's link): } \\
\text { http://www.rtve.es/alacarta/audios/el-septimo- }\end{array}$ \\
& $\begin{array}{l}\text { vicio/septimo-vicio-kossakovsky-quiere-tolentino-su- } \\
\text { proxima-pelicula-13-03-13/1719334/ }\end{array}$ \\
\hline Broadcast participants: & Javier Tolentino (host) (JT). \\
\hline
\end{tabular}

6 The videos suggested for this exercise can be found here: http://www.letour.com/2010/TDF/LIVE/us/1700/videos.html?target=162950 . A voiceover interpretation in English (linked), German and Spanish can be accessed on the website. 


\begin{tabular}{|c|c|}
\hline & $\begin{array}{l}\text { Andrea Guzmán (guest; president of DOCMA, organiser of } \\
\text { the film event, 3xDOC) (AG). } \\
\text { Andrés Duque (guest, Spanish documentary filmmaker) } \\
\text { (AD). } \\
\text { Viktor Kossakovsky (guest, Russian documentary filmmaker) } \\
\text { (VK). } \\
\text { Interpreter, male, name unknown (IM). } \\
\text { Victoria Esparza (programme collaborator-journalist) (VE). } \\
3 \text { passers-by/filmgoers ( } 1 \text { woman, } 2 \text { men) at the Café } \\
\text { (interviewed by VE). }\end{array}$ \\
\hline Sound management: & $\begin{array}{l}\text { David Velasco (DV), Santiago Francia (SF) (in semi-outdoors } \\
\text { studio). } \\
\text { Sound production in Radio } 3 \text { Studios (Madrid): Samuel } \\
\text { Alarcón. }\end{array}$ \\
\hline Broad contextual factors: & $\begin{array}{l}\text { Organisational and situational arrangements prior to the } \\
\text { interview. }\end{array}$ \\
\hline Interpreter provider: & $\begin{array}{l}\text { Unspecified. } \\
\text { Note: The interaction suggests that it is the organisers of } \\
\text { the event (DOCMA, documentary filmmaking association) } \\
\text { and the interpreter has been hired by the organisers to } \\
\text { accompany VK to all the interpreter-mediated events } \\
\text { organised for his stay in Madrid (Q and A, masterclass, } \\
\text { media interviews, etc.). }\end{array}$ \\
\hline Reasons for interview: & $\begin{array}{l}\text { VK is in Madrid, as special guest of } 3 \times D O C \text { Encuentro de } \\
\text { Creadores ( } 3 \times D O C \text { Meeting with Creators), organised by } \\
\text { DOCMA. 3xDOC } 2013 \text { unites documentary filmmakers } A D \\
\text { and VK for a retrospective screening of some of their } \\
\text { films, followed by } Q \text { and A sessions (13th and 14th March) } \\
\text { and a public meeting with both filmmakers (15th March) } \\
\text { at the Cine Doré (the official film theatre venue for } \\
\text { Filmoteca Española). On 13th March, } 9 \text { pm, VK's film, The } \\
\text { Belovs, was scheduled to be screened. El Séptimo Vicio, } \\
\text { in collaboration with DOCMA and Filmoteca Española, } \\
\text { arranged to broadcast its live programme - by then } \\
\text { scheduled for live broadcast at } 4 \text { pm - from Cine Doré's } \\
\text { Café, interviewing the organiser, AG, and the two guest } \\
\text { filmmakers, AD and VK. }\end{array}$ \\
\hline Participants' location: & $\begin{array}{l}\text { Semi-Outdoors Studio: Café at Cine Doré. } \\
\text { Note: Frequent location for ESV broadcasts outside RTVE } \\
\text { studios. }\end{array}$ \\
\hline
\end{tabular}




\section{Broad pattern of interaction:}

\section{Face-to-face, multi-party interview.}

Table 3: Radio interview background information.

The editing of the interview for training purposes consists of muting the interpreter's renditions, leaving a time gap as long or longer than the interpreter's rendition, particularly if the exercise is used in the early stages of dialogue interpreting. The proposed software is Audacity, a free audio-editing software that features these editing tools. Two screenshots of the before and after editing are provided below:

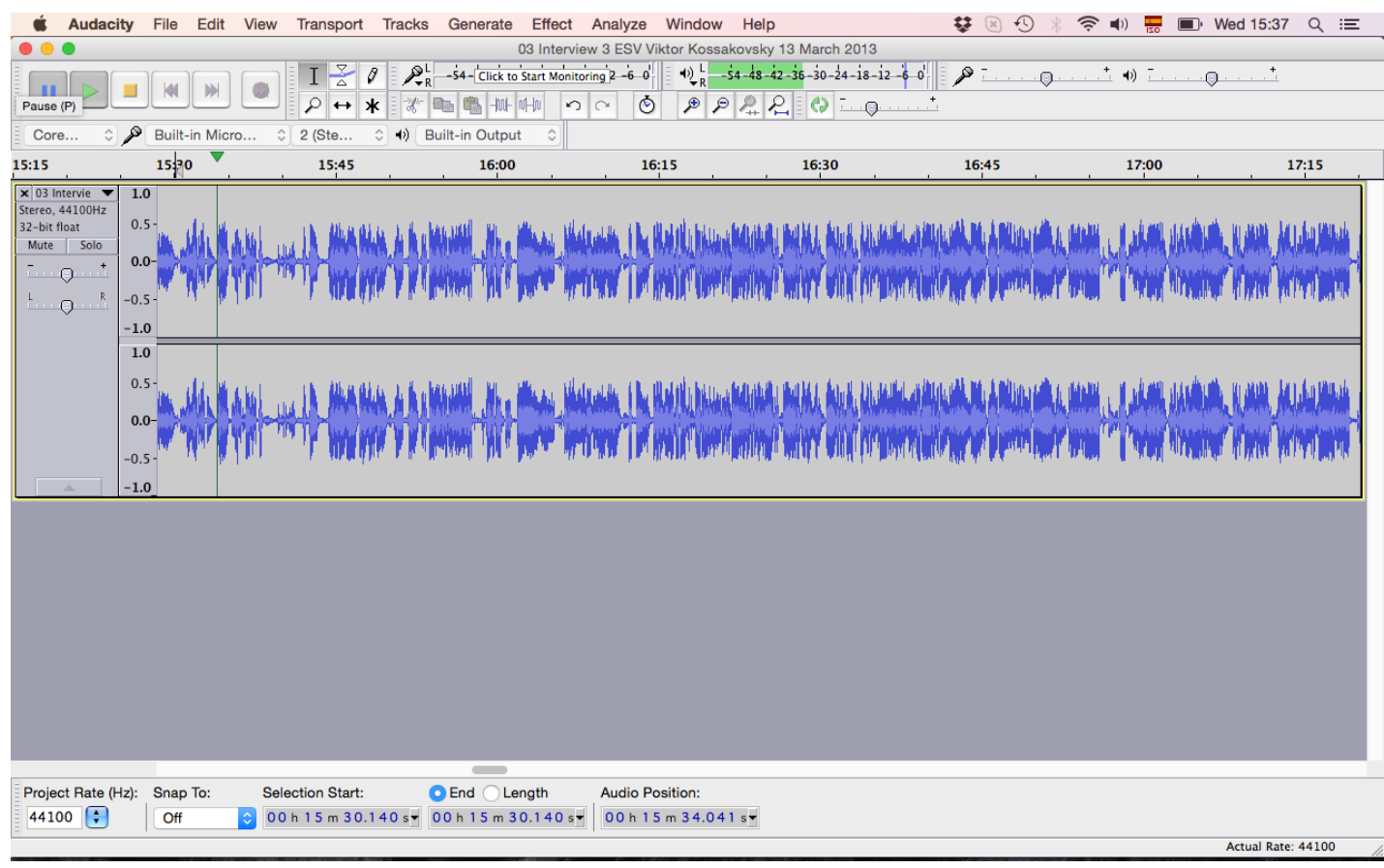

Image 1: Original audio piece 


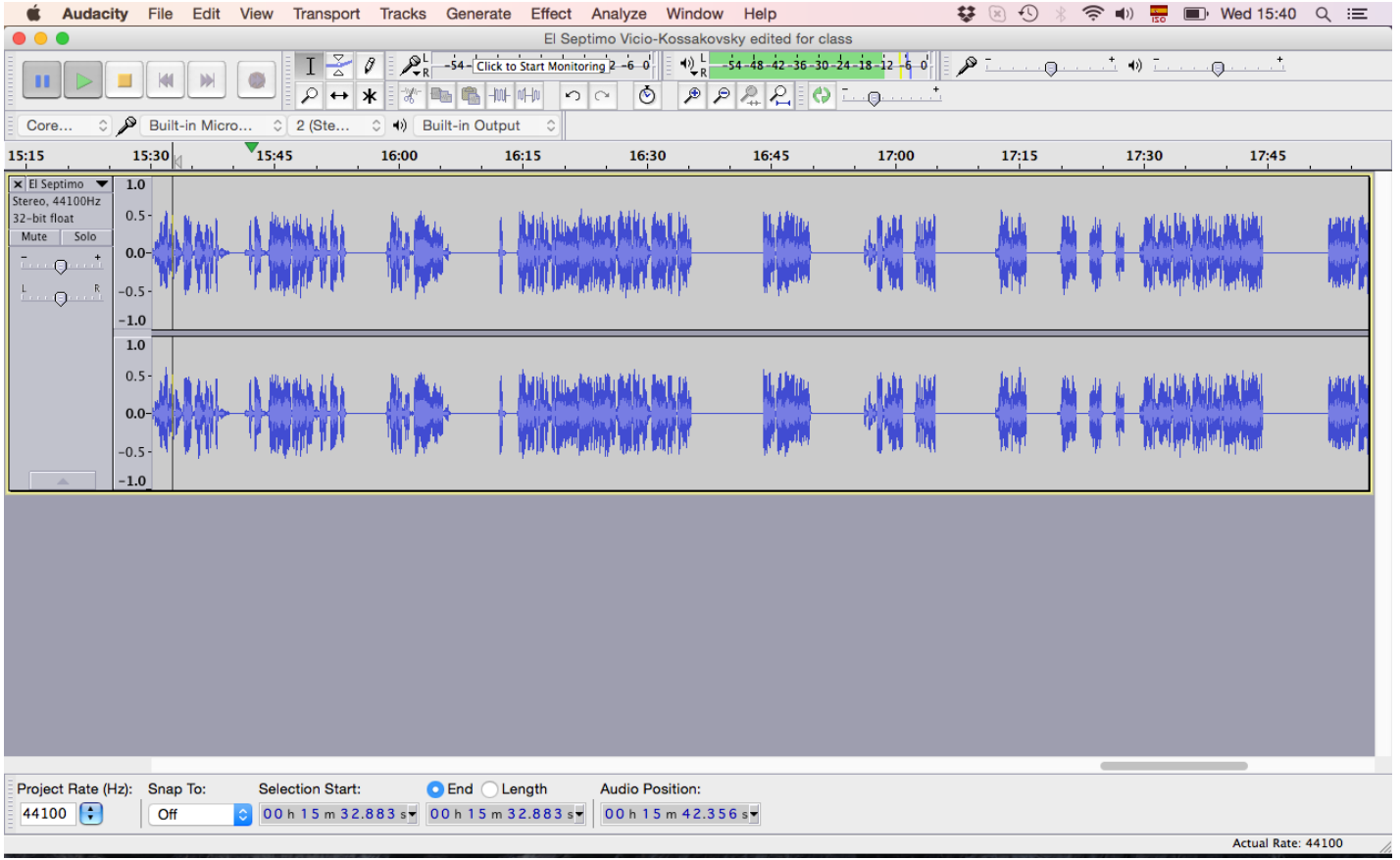

Image 2: Edited audio piece with muted interpreter renditions.

For providing feedback to students a two-fold system is proposed: first, a qualitative feedback session, using the interview transcription, either with the students' recordings or via a post-exercise discussion; second, a more reflective feedback session which consists of playing the original audio broadcast with the interpreter's rendition and allowing students to comment and compare the broadcast interpreting with their own to integrate their performance in a situated practice and, thus, encouraging them to see the value and implications of exercises based on authentic practice.

\section{Concluding remarks}

With the suggested exercises, presented as case studies, several broadcast events with a diversity of situational arrangements and interactional challenges have been presented in a systematised way.

As the two proposed exercises and the methodology for creating them show, the preparation of such materials requires a great deal of time and effort from the trainer. In fact, the work presented here is the result of nearly ten years of research on TV and radio broadcasting under different projects and over 14 years of teaching interpreting. This professional experience has convinced me that in order to pave the way for future Ml training and interpreting training overall, two steps are of fundamental importance: first is working with interdisciplinary groups (including interpreters, scholars, media stakeholders and professionals,); and second, establishing action-research projects which have the time and resources to produce pedagogically sound training materials grounded in professional practice. 
As interpreting researchers and trainers already stated with the advent of NICTs in the early 2000s (cf. de Manuel Jerez 2003), new technologies are here to stay and it is our responsibility as an academic community to look at the most efficient, motivating and systematic ways of integrating their use into interpreter training programmes. Taking advantage of authentic interpreter-mediated broadcast materials is no easy task, as I have tried to show in this article. Considerable efforts of compilation, selection and systematisation of materials need to be undertaken. Exercises have to be checked against the learning outcomes of the programmes where they are to be put into practice. And in order to replicate real-life $\mathrm{Ml}$ conditions in the classroom or in self-study sessions, thorough research into these conditions is required.

Although there are clear pedagogical advantages and ways in which the use of NICTs can improve interpreter training, we are still at an experimental stage in this actionresearch project. There are aspects of these types of exercises that can be improved by carrying out student surveys (along the lines of de Manuel Jerez, 2005) and interviews with professional media interpreters. Until very recently no Ml training has been available, so we should be able to gather valuable feedback by following up on students who now receive such training and then go on to work in the media.

The teaching of interpreting has developed hand in hand with the development of NICTs, and in the field of Ml both professional practice and training are now unthinkable without NICTs. Keeping track of how Ml practice is carried out and, most importantly, how NICTs are contributing to new developments in Ml, is essential if training institutions aim to meet the demand for highly-qualified interpreters. It is not enough for a professional media interpreter to have proficient interpreting skills; they also need to have a thorough understanding of the media and the new technologies involved in producing interpreter-mediated broadcasts. It is this gap that this article aims to fill.

\section{References}

AllC (2012). Exploring Media Interpreting. http://aiic.net/page/3851/exploring-mediainterpreting/lang/1

Bao, C. (2015). Pedagogy, in: Mikkelson, H.; Jourdenais, R. (eds.). The Routledge Handbook of Interpreting. London \& New York: Routledge, pp. 400-416.

Braun, S.; Slater, C. (2013). Dialogue Interpreting in VirtualReality: Creating Bilingual Dialogues for Interpreting Practice in a 3DVirtual Environment, in: InDialog Conference Mapping the Field of Community Interpreting. Berlin 15-16 November 2013.

Braun, S.; Slater, C. (2014). Populating a 3D virtual learning environment for interpreting students with bilingual dialogues to support situated learning in an institutional context. The Interpreter and Translator Trainer. Special issue: Dialogue interpreting in practice: Filling the gap between empirical research and interpreters' training, v. 8, n. 2, pp. 469-485. https://doi.org/10.1080/1750399X.2014.971484 
Braun, S.; Slater, C.; Gittins, R.; Ritsos, P. D.; Roberts, J. C. (2013). Interpreting in Virtual Reality: designing and developing a 3D virtual world to prepare interpreters and their clients for professional practice, in: Kiraly, D.; Hansen-Schirra, S.; Maksymski, K. (eds.). New Prospects and Perspectives for Educating Language Mediators. Tübingen: Gunter Narr, pp. 93-120.

Castillo, P. (2012). Analyzing multilingual TV/radio production: Media stakeholders' practical perceptions and awareness on interpreting, in: Languages and the Media 2012 Proceedings. Berlin: ICWE BmbH, pp. 82-85.

Castillo, P. (2015a). Interpreting in the Media: Organizational, Interactional and Discursive Aspects of Dialogue Interpreting in Radio Settings: A study of Spain's Radio 3 [PhD Thesis]. Heriot-Watt University. Edinburgh.

Castillo, P. (2015b) Interpreting for the Mass Media, in: Mikkelson, H.; Jourdenais, R. (eds.). The Routledge Handbook of Interpreting. London \& New York: Routledge, pp. 280-301.

Castillo, P.; Comte, G. (2010). The Role of the Broadcaster in an Interpreter-Mediated Radio Interview [DVD Documentary].

Castillo, P.; Comte, G. (2011). The Behind the Scenes Journey of TV Interpreting [DVD Documentary].

Colina, S.; Angelelli, C. (2017). Translation and Interpreting Pedagogy in Dialogue with Other Disciplines. Amsterdam/Philadelphia: John Benjamins. https://doi.org/10.1075/bct.90

Berber D. (2008). ICT (Information and Communication Technologies) in conference interpreting: a survey of their usage in professional and educational settings). http://isg.urv.es/cetra/article_CETRA2007_berber.pdf

Daly A. (1985). Interpreting for international satellite television. Meta: Journal dels Traducteurs $=$ Translators' Journal, v. 30, n. 1, pp. 91-96. https://doi.org/10.7202/002445ar

Darwish A. (2006). Standards of simultaneous interpreting in live satellite broadcast: Arabic case study. Translation Watch Quarterly, v. 2, n. 2, pp. 55-106.

De Manuel Jerez, J. (coord.) (2003). Nuevas tecnologías y formación de intérpretes. Granada: Atrio.

De Manuel Jerez, J. (2006). La incorporación de la realidad profesional a la formación de intérpretes de conferencias mediante las nuevas tecnologías y la investigaciónacción [Tesis doctoral]. Departamento de Traducción e Interpretación Universidad de Granada. Granada. https://hera.ugr.es/tesisugr/15891574.pdf

EMCl (2014). Aims. https://www.emcinterpreting.org/aims

EMCI (2017) EMCl Core Curriculum. https://www.emcinterpreting.org/application/files/4115/1724/1320/EMCl_Core_Curricu lum-080917.pdf 
Falbo C. (2012b). CorlT (Italian Television Interpreting Corpus): classification criteria, in: Straniero Sergio, F.; Falbo, C. (eds.). Breaking Ground in Corpus-based Interpreting Studies. Bern: Peter Lang, pp. 155-185.

Falbo, C. (ed.) (2011) The Interpreters' Newsletter. Special Issue on Television Interpreting, 16. Trieste: Edizioni Università di Trieste.

Fantinuoli, C. (2018). Interpreting and Technology. Berlin: Language Science Press.

Gentile, A. (1997). Community Interpreting or Not? Practices, Standards and Accreditation, in: Carr, S.; Roberts, R.; Dufour, A.; Stein, D. (eds.). The Critical Link: Interpreters in the Community. Amsterdam/Philadelphia: John Benjamins, pp. 109118. https://doi.org/10.1075/btl.19.13gen

Gieve, S.; Norton, J. (2007). Dealing with linguistic difference in encounters with Others on British television, in: Johnson, S.; Ensslin, A. (eds.). Language in the Media. London: Continuum, pp. 188-210.

Gile, D. (2009). Basic Concepts and Models for Interpreter and Translator Training. Revised Edition. Amsterdam/Philadelphia: John Benjamins. https://doi.org/10.1075/btl.8

Gillies, A. (2019). Consecutive Interpreting: A Short Course. London: Routledge. https://doi.org/10.4324/9781315648972

Gómez, M. A.; Weinreb, S. (2002). An Alternative Instructional Model: Teaching Medical Translation Online. Meta: Journal des Traducteurs = Translators' Journal, v. 47, n. 4, pp. 643-648. https://doi.org/10.7202/008044ar

González-Davies, M.; Enríquez-Raído, V. (2016). Situated learning in translator and interpreter training: bridging research and good practice. The Interpreter and Translator Trainer, v. 10, n. 1, pp. 1-11. https://doi.org/10.1080/1750399X.2016.1154339

ISIT (2015). Impact des nouvelles technologies et plus particulièrement de la visioconférence sur l'enseignement de linterprétation de conférence". Connecting Conference interpreting trainers : Project report. https://www.isit-paris.fr/wpcontent/uploads/2015/09/ISIT-DGINTER_Synthese juillet2015.pdf

Jiménez Serrano, O. (2011). Backstage conditions and interpreter's performance in live television interpreting: quality, visibility and exposure. The Interpreters' Newsletter, $\mathrm{n}$. 16, pp. 115-136.

Katan, D.; Straniero Sergio, F. (2001). Look who's talking: The ethics of entertainment and talkshow interpreting. The Translator, v. 7, n. 2, pp. 213-237. https://doi.org/10.1080/13556509.2001.10799102

Katan, D.; Straniero Sergio, F. (2003). Submerged ideologies in media interpreting, in: Calzada Pérez, M. (ed.). Apropos of Ideology. Manchester: St. Jerome, pp. 131-144.

Kiraly, D. (2015). Towards Authentic Experiential Learning in Translator Education. Mainz: V\&R Unipress. https://doi.org/10.14220/9783737004954 
Kiraly, D. (2000). A Social Constructivist Approach to Translator Education: Empowerment from Theory to Practice. Manchester, UK/Northampton MA: St. Jerome.

Krone, E. (2010). Voiceover of Videos for Internet Broadcasting: Translation, Voice Recording and Audio Editing on Basic Notebook Computers, in: ICWE GmbH (ed.) Languages and The Media 8th International Conference: New Media - New Contexts - New Translator Profiles? Conference Book of Extended Abstracts. Berlin: ICWE.

Kurz, I. (1997). Getting the message across: Simultaneous interpreting for the media, in: Snell-Hornby, M.; Jettmarová, Z.; Kaindl, K. (eds.). Translation as Intercultural Communication. Amsterdam: John Benjamins, pp. 195-206.

Kurz, I. ; Bros-Brann, E. (1996). L'interprétation en direct pour la télévisión, in: Gambier (ed. Les Transferts Linguistiques dans les Médias Audiovisuels. Villeneuve d'Asq (Nord): Presses Universitaires du Septentrion, pp. 207-215.

Martin, A. (2015). La formación en interpretación en España: pasado y presente, in: MonT/ Special Issue 2, pp. 87-110. https://doi.org/10.6035/MonTI.2015.ne2.3

Mikkelson, H. (2009). Interpreting is interpreting - or is it?. The Al/C Webzine. December 14. http://aiic.net/p/3356 .

Mikkelson, H.; Jourdenais, R. (eds.). The Routledge Handbook of Interpreting. London \& New York: Routledge.

Mizuno A. (1997). Broadcast interpreting in Japan: some theoretical and practical aspects, in: Gambier, Y.; Gile, D.; Taylor, C. (eds). Conference Interpreting: Current Trends in Research. Amsterdam/Philadelphia: John Benjamins, pp. 192-194.

Molina Vallecillo, J. (2002). La Interpretación simultánea en las cadenas de TV estatales españolas: aspectos técnicos, situacionales y emocionales. Puentes, n. 1 , pp. 95-106.

Pacheco Aguilar, R. (2015). The Questions of Authenticity in Translator Education from the Perspective of Educational Philosophy, in: Kiraly, D. (ed.). Towards Authentic Experiential Learning in Translator Education. Mainz: V\&R Unipress, pp. 13-32. https://doi.org/10.14220/9783737004954.13

Pöchhacker, F. (2007). Coping with culture in media interpreting. Perspectives, v. 15, n. 2, pp. 123-142. https://doi.org/10.1080/13670050802153798

Sandrelli, A. (2012). Interpreting Football Press Conferences: The FOOTIE Corpus, in: Kellett, C. J. (ed.). Interpreting across Genres: Multiple Research Perspectives. Trieste: EUT Edizioni Università di Trieste, pp. 78-101.

Sandrelli, A. (2015). Becoming an interpreter: the role of computer technology. MonTI, Monografías de Traducción e Interpretación, Special Issue 2, pp. 111-138. https://doi.org/10.6035/MonTI.2015.ne2.4

Sandrelli, A.; De Manuel Jerez, J. (2007). The Impact of Information and Communication Technology on Interpreter Training: State-of-the-art and Future Prospects. The 
Interpreter and Translator Trainer, v. 1, n. 2, pp. 269-303.

https://doi.org/10.1080/1750399X.2007.10798761

Scannell, P. (1988). The communicative ethos of broadcasting. Paper presented at the International Television Studies Conference. London, BFI.

Seleskovitch, D. (1978). Interpreting for International Conferences. Washington, DC: Pen \& Booth.

Straniero Sergio, F. (1999). The interpreter on the (talk) show: interaction and participation frameworks. The Translator, v. 5, n. 2, pp. 303-326. https://doi.org/10.1080/13556509.1999.10799046

Straniero Sergio, F. (2003). Norms and quality in media interpreting: the case of formula one press conferences. The Interpreters' Newsletter, v. 12, pp. 135-174.

Straniero Sergio, F. (2011). What television can tell us about interpreting. Falbo, C. (ed.) The Interpreters' Newsletter. Special Issue on Television Interpreting, 16. Trieste: Edizioni Università di Trieste, pp. XII-XV.

Straniero Sergio, F. (2012). 'You are not too funny': Challenging the role of the interpreter on Italian talkshows, in: Baraldi, C.; Gavioli, L. (eds.) Coordinating Participation in Dialogue Interpreting. Amsterdam: John Benjamins, pp. 71-98. https://doi.org/10.1075/btl.102.04str

Shibahara T. (2009). Broadcasting interpreter: a comparison between Japan and UK, in: Díaz Cintas, J.; Anderman, G. (eds.). Audiovisual Translation: Language Transfer on Screen. London: Palgrave Macmillan, pp. 140-148. https://doi.org/10.1057/9780230234581_11

Tymczyńska, M. (2009). Integrating in-class and online learning activities in a healthcare interpreting course using Moodle. Jostrans, n. 12, pp. 149-165.

Zhong, Y. (2010). Struggling Between Aspirations to Innovate and the Tyranny of Reality. International Journal of Interpreting Education, v. 2, pp. 165-175. 